この早期副作用を都内 4 大学, 施設で集計した成續は表 3の如くである．この中*印は凍結したすのを使用した 場合の 1 例を含む副作用である．190例 664回使用によ る副作用は22例で，注射回数に対する副作用発生率は 3.4\%である.これは初期製剤の副作用であり，最近で は, 殆ど認めていない。
今後完全静脈内栄証補給(Total paraenteral nutrition) には，この隻珴がますます使用されるよらになるである 5 .

以上術後の脂質補給について, 量, 質の面より檢討を 加克た。

\title{
消化吸収試験
}

患者さんの栄盖指導でチェックすべき点, 消化吸収の 実際的な問題点をいくつかの試験法を紹介しながらのベ てまいります。

消化管の広範囲の切除や食事通路の大きな変更がある と,このスライドに示す各種の要因が重なりあつて, そ の必然の結果として消化吸収障害が起ります．例えば席 頭十二指腸切除や小腸広範切除などでは，適切な栄養管 理なしに健康な生活は送れません，又，安全な手術とし てどこでる行なわれている胃切除術のあでる，近年に なつてこのスライドのように各種の栄養障害が検出され てきています。このような病態を明らかにする目的で， 消化吸収試験は臨床外科で実施されます。

普通言ら消化吸収試験は吸収に関係した検索が多いの でその前にまず消化に関係した検索手段として，私達 が開発した方法について説明しながら，術後の栄垬間題 との関連を論してゆきすす。

最初に, 術後患者の食事指道に拉いて, 第一に強調さ れるべき点は，消化の前提となる勗虂による食物の機械 的粉砕の重要性です.

この単純な作業が，例えば三回余分にかむと理想的に は 1 個が 3 つのディメンジョンで 8 分割されて，その結 果消化液に接する表面面積の增加と消化液の内部へのし みこみを考えれば，消化の効率を躍進させることは明ら かであります。

第 2 に消化の前提となる大切な問題には，スライドに （1）としるした「食物と消化液の混和」があげられま す.胃のなかで食物と消化液がどの部分でどのようにし て混和されるかの具体的なことについては，漠然と考え られていたよらです.この点に関し本学放射線科遠山助 教授の追究は，食物の擋拌混和は胃のなか全体ではなく
千葉大第 2 外科広 田和 俊

て閒前庭部で主に行なわれることを明らかにしまし た.

では, 胃の手術後はどらか, 同じ方法を用いて, 私達 は胃の各種手術の遠隔時に検討しました。 その方法は, 食事をとる間に特定の形の造影剂の粒を，一定間隔で 4 回に内服させ，X線でその動きを追究するすのでありま す. 造影剤は微細な球型, 立方型, 円柱型, 細碀型の四 種類の形で、フルギン酸カルシュウムでバリウムをつつ んた微細なものです．この四つの形のるの10個づつを， 同し時間間隔で食事に挾んで内服させて，その粒のひろ がり，まさり具合から，その食事の摚拌混和状態を観察 することができます，又，これまでの方法ではとられに くかつた食事の胃からの排出状態る把握できるよらにな

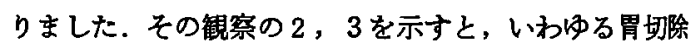
術では，ほとんど混和擋拌がみられず，食事の胃に入つ てきた順に十二指腸，空腸にトコロテンの押し出し式に 排出されてゆくのがわかります，食事終了直後です，胃 にわずかしか残つていません．ことにダンピング晸候を 有する患者では, 食事終了 1 分後に，胃のなかにほとん ど残つていません．これに反して同じ消化性㵒場に対す る手術でも，昨日のシネシンポジウムで申述べた胃を切 除しない迷走神経切離十前壁固定兼幽門成形術の患者で は，食事直後から健康人と同しく，幽門前庭部を中心と して食物の傥拌混和が盛んに行なわれるのが観察でさま す.つまり，この術式では胃のなかに括ける消化のFirst Stepがよく行なわれていることを示しています. 術式か゚ かわつて噴門切除の患者群では二つのハターンを示しま した。一つのバターンは，四種類の造影剤の粒がよく擋 拌されている型で，もら一つのパターンはトュロテンの 押し出し式に十二指腸にでてゆく排出の速い型です．以 
上の例からかかるように，これまで具体的に把握しにく かつた胃のなかでの普通の食事の擋拌混和状態や，胃か らの排出状態をこの方法によつて観察し, 臨床症状との 関連を求めてゆくことは, 各手術後の病熊生理を明らか にするらえでの新しい視点と考兵ます。

消化の第三の問題として消化液分泌があります。胃分 泌関しては広沉多吱な研究があるので，ここでは省略 して2つの点を強調するにとどめます.一つは胃分泌の 試験法として，古典的なカチカルク法よりる，注射によ るインシニリン・ヒスタローグ・ガストリン制激を用い るのが, 現今の試験法であることです. 他の一つは，食 物が胃のながあるときには，消化に大きな働きをする 胃酸とペブシンの一過性の分泌が望をれます。それがた とえ消化性謴瘍に対する術式であつてる同しことです. この意味では, 胃を切除しない胃迷走神経切離, 前壁固 定兼幽門成形衍は脳相は分泌零でる，食物が幽門前庭部 を刺激した時だけ分泌がられる術式であつて，より合 理的な街式であると申せましょう。

さて以上の食物の咀礵, 胃液との擋拌混和, 胃液によ る化学変化, の3つの消化の過程か総合されて, 消化全 体としてどのように行なわれるか，についての検査法も 簡便で実用的なるのは見当りませんでした：私達はこの 点をる解明するため，小さなバリウムの粒のまわりを卵 白蛋白質で均等の厚さにニーティングした錠哓を開発し ました．これを患者に10個内服させて，3時間と 5 時間 後にX線撮影を行なつて，その形と数とを観察し，蛋白 か消化を受けるにつれてパリウムの形が変化し崩れて消 失する具合から，消化の程度を知ることができます。 のX線写真の変化を 5 つの型に分類しています．この方 法は，臨床的に簡単に施行できて患者に苦痛を与えず， 同一症例婂くりかえして実施が可能であるなどの特色を もつています，そしてこの試験法は胃腸の運動機能をも 含めて，消化管内での卵白の実際の消化状態を把握でき る㭘查法です．この方法により術前でる術後でる，從来 消化吸収が不良な場合区別がずかしかつた消化不全と 吸収不全を区別することができす，又，消化不全に対 する対策として，消化剂の効果も観察できます。

さて吸収に関する試験法としては，1937年 Hamilton が無機物のアイントーブを経口投与したのに始まりま す，有機物のフイントープの場合は，消化と吸收とを総

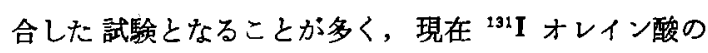
他，数種の物質がよく用いられています。いずれる経口 投与したのち，血中放射能の推移から吸収の速度と量を 推定したり，供便や尿中の放射能から，代謝や排泄につ
いて推定する試験です，実施の実際について詳細をのぺ る余地がありませんが，総括的に言うならばこれら放射 性物貿による追跡方法は，放射能を付与したその物質に 関しては，生体の出納ばかりでなく，生体内部での代謝 過程も追跡しうるので，これまで疾患や症候の原因分析 に威力を発揮してきました，外科では，例吝ば胃手術後 の大赤血球性筫血はビタミン $\mathbf{B}_{12}$ の吸収障害に起因し, オステオプローシス，オステオマラシフは VD, Ca, P, などの障害によることが明白にされました。このように 有力な研究手段である反面, 入手しやすいフイソトーフ に限定されてくるので, 特定の元素, 特定の化合物だけ の追跡が可能となります，従つて消化吸收機能の㭘索と いっても，その単一物質の代謝を通して観察している点 に限界があります。これに対して，䔬便による Balance Study は, 単一の物質ではなしに, 普通, 蛋白質全体, 脂肪全体, 炭水化物全体を先れぞれ一括して, 経口的に 入つたものがどれ位吸収されないで䔬便中出たかを測 定して消化吸収を測定します.一般的な術後患者の体力 減退, 栄羡低下は個々の物質よりす栄堆素全体の吸収不 全として把えられる場合が多いのです，例光ば粨頭十二 指腸切除では，蛋白質，脂肪全体として著るしい消化四 収摔の低下を示します。胃の切除手術のうちでる体部切 除恃正常値を示し, 噴門切除, 食道胃吻合では蛋白の軽 度の吸收率低下を示するのがながは注あり，幽門側切除 となると低下の頻度む增してきて脂肪にも变化がでてき ます。噴門切除食道空腸吻合では, 蛋白, 脂肪とも吸収 障害がかなり著明となつて，特に脂肪で強調されてくる が，胃全剔出となると更に明瞭にあらわれてきます。こ れらの検査は昔から行なわれている試験食と筫便の一定 期間中の全量採集法でる可能でありましたが繁郘で手間 がかかり実施が容易ではありません。そこでIrwin，Crampten が1951年, 人に応用した $\mathrm{Cr}_{2} \mathrm{O}_{\mathrm{s}}$ を標識とする比 率法を1954年私達は外科臨床に応用しました。この方 法は現在広く普延されて実施されているので詳細は省き ますが，古典的な全量採取法の各種の欠点が改善された ばかりでなく，古典的な方法では望みうべくもなかつた 梌索まで可能となりました。すなわち比率法では排便ご との個々の䔬便についての消化吸収率の算定が可能であ るから，患者の状況の変動に応じたデータが得られま す. 例党ば，手術後の消化吸収機能の回復動驡を分析把 暒し得て, 術後早期栄羡の問題に資料を与克ましたし, あるいは，各手術々式の消化四収機能の安定性を明らか にしました，又莐物を投与したり，特定栄盖素を負荷し た場合のそれぞれの消化吸収の变化子捉充得ました。さ 
らに，動物実験では，屠殺によつて腸管各部位の内容を 採取分析することによつて，消化管内部の吸収率推移を 具体的に把握して，手赫後の代偵状況をらかがうことも できますこの $\mathrm{Cr}_{2} \mathrm{O}_{3}$ 標識による比率法も， $\mathrm{Cr}_{2} \mathrm{O}_{3}$ の 定量法が最近簡易化されたり，卓上電子計算機の利用に よつて，データ処理，計算が簡易化されてきています。
以上，私達が手がけてきた消化吸収の検索のための試 験法について述へてきましたが，それそれれの試験法にそ の特色と限界とがあり, 臨床上の検索目的に応した試験 法が選ばれねばなりません，又，その夷施が簡単容易と なるように，今後の改良が望まれる点も多いのでありま 广.

\section{Tube Feeding}

東京医科歯科大第 2 外科 木村 信良 石田 清

\section{Tube Feeding のあらまし}

1. Tube Feeding とは

Tube Feeding 即ち経管栄養法とは，消化管内一 tube を挿入，留㯰し流動性栄差物を与える方法を総称し，外 科領域ではかなり古くから行なわれています．今回は主 として胃手術後に我々の行なつておりましたTube Feeding の概略と，今まてに行なわれたそれに関連する教 室の研究の一部を述べさせて頂きます。

\section{2. tube の種類}

大きく分けて単管と二重管とがあります。二重管の特 徵は，十二指腸又は空腸に栄養物を注入するための注入 管と，胃内眝留物を吸引するための吸引管とが併置され ていることで，注入口は最先端にあり，それから30cma 側，吸引口のある部分までは単管で，吸引口から口側は 二重管になつています。

\section{3. 注入栄䖯物}

举盖量がそれぞれの病態に適したもので，かつ副作用 をおこさないるのを用いるのが原則で，今日ではこの目 的のためにかなり安定した製品も得られるようになりま した. 又，注入栄養物に対する腸粘膜の耐性について は，個々の症例にっいて予知できないわけであります が，臨床的にたとえば，始めは栯質のみ注入して次第に 腸粘膜の機能に順応させてゆく必要性なと゚を考虑します と，混合栄盖剂として使用することのほかに，それぞれ の栄養素が単一のるのとして使用でき，個々の病態に㡱 して処方が変えられることる望ましいと思われます。

4. Tube Feeding $の$ 長所, 短所

Tube Feeding は手術後の栄童補給を行なう際の，量 的及び質的内容からみて，静脈内栄養法と释口栄盖との 中間に位するすのと考兵られます，本法の長所は，1）長
期にわたり経口攝取が困難と予想される場合に適してい ること，2)高張性脱水にさえ注意すれば，静脈内注射に よる場合の如き，血液・脳関門の選択的透過珄中循䅫采 への影響に配虑する必要がほとんどないこと，3)患者の 食欲の有無に関係なく，ほぼ必要栄養量を注入し得るこ と，4)静脈内栄盖法のときほど䍃密な無菌的操作を考虚 する必要がないことなどの点であります.

しかし Tube Feeding においても体内利用や臨床上の 愁訴, 副作用と関連し，栄養郕の濃度，注入量，注入速 度などにはおのずからある制約があります．臨床上比較

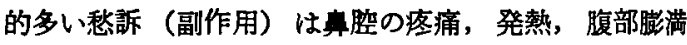
感, 咽頭部痛, 異物感, 口渴, 下痢, 悪心, 呕吐, 痰の からみなどが举げられています， tube 自体の Tube Feeding 障害因子としては tube の屈曲, 閉塞があります。

II. 教室で行なつていた Tube Feeding について 本年 4 月までの過去約15年間に教室で施行しました成

\section{図表 1 胃手術息者の術後栄養法}

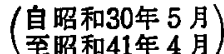

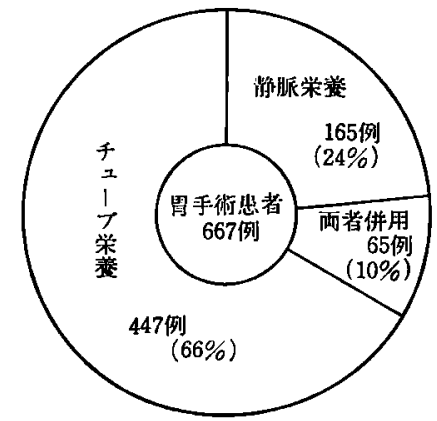

チェーブ栄业施行率：併用例を加えると76\% 